\title{
Assessment of complications in treating the fracture around knee joint by using locking compression plate
}

\author{
Surender Kumar' ${ }^{1}$, Himanshu Khichar ${ }^{2 *}$
}

\author{
${ }^{1}$ Department of Orthopedics, Government Hospital, Barmer, Rajasthan, India \\ ${ }^{2}$ Department of Orthopedics, Pacific Institute of Medical Sciences, Umarda, Udaipur, Rajasthan, India
}

Received: 05 January 2021

Revised: 19 January 2021

Accepted: 20 January 2021

\author{
*Correspondence: \\ Dr. Himanshu Khichar, \\ E-mail: drrattirammeena@gmail.com
}

Copyright: () the author(s), publisher and licensee Medip Academy. This is an open-access article distributed under the terms of the Creative Commons Attribution Non-Commercial License, which permits unrestricted non-commercial use, distribution, and reproduction in any medium, provided the original work is properly cited.

\begin{abstract}
Background: Aim of the study was to describe complications and problems in treating the fracture around knee joint by using LCP (locking compression plate).

Methods: This multicentric prospective functional out-come study has been conducted in the department of orthopedics, Barmer medical college and hospital, Barmer, Rajasthan and department of orthopedics, Pacific institute of medical sciences, Udaipur, Rajasthan. A total of 90 patients were studied, out of which 60 patients were with fracture distal femur and 30 patients were with proximal tibia fractures.

Results: Out of 44 patients of distal femur fracture group $10(22.72 \%)$ had infection where as in proximal tibia fracture group $4(15.38 \%)$ out of 26 patients (all were operated by ORIF technique) had infection. Varus deformity was found in 3 patients $(6.66 \%)$ of distal femur fracture patients and 4 patients $(15.38 \%)$ of proximal tibia fracture patients out of these 3 were operated by ORIF and 1 by MIPO. Muscle wasting was found in 20 patients (40.44\%) of distal femur fracture patients. Limb shortening was found in 7 patients $(15.90 \%)$ of distal femur fracture. Limp shortening was present in 17 patients $(38.60 \%)$ of distal femur fracture and 4 patients $(15 \%)$ of proximal tibia fracture out of these 4 were operated by ORIF and 1 by MIPO. Delayed Union was found in two patients $(4.54 \%)$ of distal femur fracture patients. Non-union with plate breakage and Non-union with plate loosening each were found in one patient $(2.25 \%)$. Extension lapse was found in four patients $(9.09 \%)$ of distal femur fracture and 1 patient $(5.88 \%)$ of proximal tibia fracture.
\end{abstract}

Conclusion: We concluded that MIPO technique was best.

Keywords: Complication, Femur, Tibia, Infection, Compound

\section{INTRODUCTION}

Locking plates potentially provide increased stability in these cases to a degree that a second plate is not required. The increased stability is the result of the difference in the mechanics of conventional plate and locking plate fixation. Stability is maintained at the angular stable screw plate interface. As a result of this stable mono block of the locking internal fixator, the pullout strength of locking head screws is substantially higher than that of conventional screws. Because the screws are locked to the plate, it is difficult for one screw to pull out or fail unless all adjacent screws fail.

LCP heals fractures by secondary bone healing (enchondral ossification). Secondary bone healing occurs when relative stability is provided and strain (change in fracture gap/fracture gap) is kept between 2 and $10 \% .^{1-3}$ Secondary bone healing is characterized by callus formation. Other methods by which fracture heals by secondary bone healing are splints, casts, intramedullary nail and external fixators. ${ }^{6}$ Stability determines the amount 
of strain at the fracture site and strain determines the type of healing that can occur at fracture site. Primary bone healing occurs when strain is kept to less than $2 \%$. Bone cannot be formed when strain is greater than $10 \% .{ }^{4}$ The increase in stability provided by locking plates is most helpful to surgeons treating a fracture in poor-quality bone, comminuted bicondylar fracture for which a single plate may not provide adequate stability. Also, since only a single plate is needed and the plate does not depend on a tight fit to the bone for stability, substantially less soft tissue dissection may be required, thus preserving the local blood supply and enhancing fracture healing. ${ }^{5}$

\section{METHODS}

This multicentric prospective functional out-come study has been conducted in the department of orthopedics, Barmer medical college and hospital, Barmer, Rajasthan and department of orthopedics, Pacific institute of medical sciences, Udaipur, Rajasthan from 1/12/2018 to 31/7/2020

Sampling technique used for the study-systematic random sampling-

\section{Sample size- $n=4 p q / 1^{2}$}

$\mathrm{P}=$ Distal femoral fractures currently account for less than $1 \%$ of all fractures, $\mathrm{q}=1-\mathrm{P}, \mathrm{l}=$ Margin of error, Minimum sample size $=15$ patients.

This multicentric prospective functional out-come study has been conducted in the department of orthopedics, Barmer medical college and hospital, Barmer, Rajasthan and department of orthopedics, Pacific institute of medical sciences, Udaipur, Rajasthan. A total of 90 patients were studied, out of which 60 patients were with fracture distal femur and 30 patients were with proximal tibia fractures. At the end of study, 20 patients were lost to the follow-up (16 patients were with distal femur fracture and 04 patients were with proximal tibia fracture).

\section{Inclusion criteria}

Inclusion criteria for the study included the all patients who got admitted in orthopedic department with closed or compound fractures around knee joint (either distal $1 / 3^{\text {rd }}$ femur or proximal $1 / 3^{\text {rd }}$ tibia) regardless of patients, sex and side, skeletally mature patient and non union distal $1 / 3^{\text {rd }}$ femur or proximal $1 / 3^{\text {rd }}$ tibia.

\section{Exclusion criteria}

Exclusion criteria for the study excluded the fracture distal $1 / 3^{\text {rd }}$ femur or proximal $1 / 3^{\text {rd }}$ tibia with vascular injury, floating knee injuries, skeletally immature patients (age $<18$ years), all patients were evaluated clinically at the time of admission and first aid treatment was given, for distal femur fracture radiograph of entire femur with one joint above and one joint below taken and for proximal tibia fracture radiograph of entire leg with one joint above and one joint below was done to assess the type of fracture and displacement and plan of the treatment.

History, general examination and local examination were recorded on the proforma attached. Patient was investigated completely for operative and anesthesia purpose. Associated medical problems were evaluated and taken care before patient is taken for operation.

\section{Statistical analysis}

Statistical analysis will be done by SPSS software (20.0 trial version) and appropriate statistical tests were used for finding the final results.

\section{RESULTS}

Majority (31.67\%) of the patients with distal femur fracture were of 28-37 yrs. age group while majority $(66.66 \%)$ of the patients with proximal tibia fracture were of $28-37$ years $(33.33 \%)$ and $38-47$ years $(33.33 \%)$ age group.

Majority of the patients with distal femur fracture (75\%) as well as proximal tibia fracture $(77.67 \%)$ were male. The association between femur fracture and age was found statistically Insignificant and association between tibia fracture and age was found statistically significant.

Table 1: Distribution of type of fracture according to age and sex $(n=90)$.

\begin{tabular}{|lllllll|}
\hline $\begin{array}{l}\text { Age group } \\
\text { (in years) }\end{array}$ & $\begin{array}{l}\text { Femur } \\
\text { Male (\%) }\end{array}$ & Female $(\%)$ & Total $(\boldsymbol{\%})$ & Male $(\%)$ & Female $(\%)$ & Total $(\%)$ \\
\hline $\mathbf{1 8 - 2 7}$ & $10(16.66)$ & $2(3.33)$ & $12(20.00)$ & $3(10.00)$ & $0(0.0)$ & $3(10.00)$ \\
\hline $\mathbf{2 8 - 3 7}$ & $16(26.67)$ & $3(5.00)$ & $19(31.67)$ & $10(33.33)$ & $0(0.00)$ & $10(33.33)$ \\
\hline $\mathbf{3 8 - 4 7}$ & $8(13.33)$ & $2(3.33)$ & $10(16.67)$ & $6(20.00)$ & $4(13.33)$ & $10(33.33)$ \\
\hline $\mathbf{4 8 - 5 7}$ & $7(11.67)$ & $2(3.33)$ & $9(15.0)$ & $1(3.33)$ & $3(10.00)$ & $4(13.33)$ \\
\hline $\mathbf{5 8 +}$ & $4(6.66)$ & $6(10.00)$ & $10(16.66)$ & $3(10.00)$ & $0(0.00)$ & $3(10.00)$ \\
\hline Total & $45(75.0)$ & $15(25.0)$ & $60(100.0)$ & $23(77.67)$ & $7(22.33)$ & $30(10.00)$ \\
\hline P value & 0.091 & & & 0.015 & & \\
\hline
\end{tabular}

Majority of distal femur fracture $(66.67 \%)$ and proximal tibia fracture $(70 \%)$ patients combined (conventional and locking) principle of locking plate fixation was used. While in $33.33 \%$ of distal femur and $30 \%$ of proximal tibia 
fracture patients internal fixation (locking screw only) principle of plate fixation was used.

Table 2: Distribution of principle used for implant fixation $(n=90)$.

\begin{tabular}{|lllll|}
\hline Principle & Femur & \multicolumn{3}{c|}{ Tibia } \\
\hline $\begin{array}{l}\text { Combined } \\
\text { (conventional } \\
\text { and locking) }\end{array}$ & 40 & 66.67 & 21 & 70.00 \\
\hline $\begin{array}{l}\text { Internal } \\
\text { fixation } \\
\text { (locking }\end{array}$ & 20 & 33.33 & 9 & 30.00 \\
only) & & & & \\
\hline Total & 60 & 100.00 & 30 & 100.00 \\
\hline
\end{tabular}

Table 3: Distribution of duration of stay in hospital $(\mathbf{n}=90)$.

\begin{tabular}{|lllll|}
\hline Days & Femur & \multicolumn{3}{c|}{ Tibia } \\
& No. & \% & No. & \% \\
\hline$\leq 4$ & 42 & 70.00 & 23 & 76.67 \\
\hline$>\mathbf{4}$ & 18 & 30.00 & 7 & 23.33 \\
\hline Total & 60 & 100.00 & 30 & 100.00 \\
\hline
\end{tabular}

Post op. hospital stays for distal femur fracture patient were 2-30 days average was 4.11 days. While for proximal tibia fracture patients it was 3.11 days.

Table 4: Early post-operative complications $(n=90)$.

\begin{tabular}{|lllll|}
\hline Complications & Femur & \multicolumn{3}{c}{ Tibia } \\
\hline $\begin{array}{l}\text { Fever with wound } \\
\text { infection }\end{array}$ & 05 & 08.33 & 5 & 16.67 \\
\hline $\begin{array}{l}\text { Without any } \\
\text { complication }\end{array}$ & 55 & 91.67 & 25 & 83.33 \\
\hline Total & 60 & 100 & 30 & 100 \\
\hline
\end{tabular}
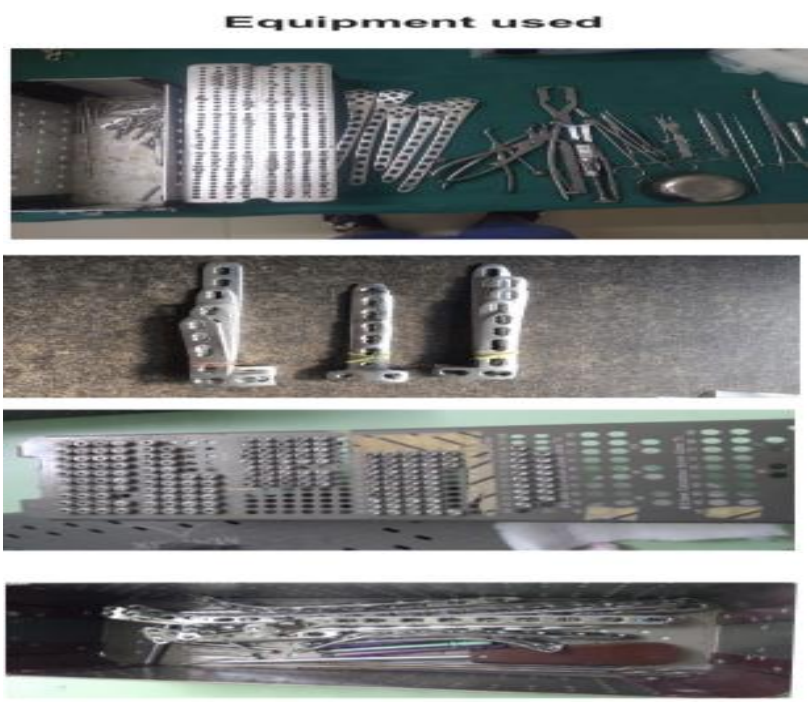

Figure 1: Equipment used.
5 patients of each distal femur fracture and proximal tibia fracture had fever with wound infection. These patients were treated by daily dressing and intravenous antibiotics. All 10 cases of wound infection were open grade $3 \mathrm{~B}$ on admission.

Table 5: Complications according to the technique used for management of femur and tibia fractures.

\begin{tabular}{|c|c|c|c|}
\hline \multirow[b]{2}{*}{ Complication } & \multirow{2}{*}{$\begin{array}{l}\text { Distal femur } \\
(\text { ORIF }) \\
(n=44) \\
(\%)\end{array}$} & \multicolumn{2}{|c|}{$\begin{array}{l}\text { Proximal tibia } \\
(n=26)\end{array}$} \\
\hline & & $\begin{array}{l}\text { ORIF } \\
(n=17) \\
(\%)\end{array}$ & $\begin{array}{l}\text { MIPO } \\
(\mathbf{n = 9 )} \\
(\%)\end{array}$ \\
\hline Infection & $\begin{array}{l}10 \\
(22.72)\end{array}$ & $\begin{array}{l}04 \\
(23.5)\end{array}$ & 00 \\
\hline Pain & $\begin{array}{l}13 \\
(29.50)\end{array}$ & $\begin{array}{l}06 \\
(35.29)\end{array}$ & $\begin{array}{l}02 \\
(22.22)\end{array}$ \\
\hline $\begin{array}{l}\text { Varus } \\
\text { deformity }\end{array}$ & $03(06.66)$ & 00 & 00 \\
\hline $\begin{array}{l}\text { Valgus } \\
\text { deformity }\end{array}$ & 00 & $\begin{array}{l}03 \\
(17.65)\end{array}$ & $\begin{array}{l}01 \\
(11.11)\end{array}$ \\
\hline $\begin{array}{l}\text { Muscle } \\
\text { wasting }\end{array}$ & $\begin{array}{l}20 \\
(44.44)\end{array}$ & 00 & 00 \\
\hline $\begin{array}{l}\text { Limb } \\
\text { shortening }\end{array}$ & $\begin{array}{l}07 \\
(15.90)\end{array}$ & 00 & 00 \\
\hline Limp & $\begin{array}{l}17 \\
(38.60)\end{array}$ & $\begin{array}{l}03 \\
(17.65)\end{array}$ & $\begin{array}{l}01 \\
(11.11)\end{array}$ \\
\hline $\begin{array}{l}\text { Extension } \\
\text { lapse }\end{array}$ & $\begin{array}{l}04 \\
(09.09)\end{array}$ & $\begin{array}{l}01 \\
(05.88)\end{array}$ & 00 \\
\hline Delayed union & $\begin{array}{l}02 \\
(04.54)\end{array}$ & 00 & 00 \\
\hline $\begin{array}{l}\text { Nonunion with } \\
\text { plate breakage }\end{array}$ & $\begin{array}{l}01 \\
(02.25)\end{array}$ & 00 & 00 \\
\hline $\begin{array}{l}\text { Nonunion with } \\
\text { plate loosening }\end{array}$ & $\begin{array}{l}01 \\
(02.25)\end{array}$ & 00 & 00 \\
\hline
\end{tabular}

Out of 44 patients of distal femur fracture group 10 $(22.72 \%)$ had infection where as in proximal tibia fracture group $4(15.38 \%)$ out of 26 patients (all were operated by ORIF technique) had infection.

13 patients $(29.5 \%)$ of distal femur fracture group and 8 patients $(30.07 \%)$ of proximal tibia group (6 patients operated by ORIF, 2 patients operated by MIPO technique) had pain.

Varus deformity was found in 3 patients $(6.66 \%)$ of distal femur fracture patients. Whereas valgus deformity was found in 4 patients $(15.38 \%)$ of proximal tibia fracture patients out of these 3 were operated by ORIF and 1 by MIPO.

Muscle wasting was found in 20 patients (40.44\%) of distal femur fracture patients. Limb shortening was found in 7 patients $(15.90 \%)$ of distal femur fracture. Limp was present in 17 patients $(38.60 \%)$ of distal femur fracture and 4 patients $(15 \%)$ of proximal tibia fracture out of these 4 were operated by ORIF and 1 by MIPO. 
Delayed union was found in 2 patients $(4.54 \%)$ of distal femur fracture patients. Non-union with plate breakage and Non-union with plate loosening each were found in one patient $(2.25 \%)$. Extension lapse was found in 4 patients $(9.09 \%)$ of distal femur fracture and 1 patient $(5.88 \%)$ of proximal tibia fracture.

Out of all the patients operated with MIPO technique for proximal tibia fracture there was only 1 patient $(11.11 \%)$ in which valgus deformity was present, 1 patient $(11.11 \%)$ had limping and pain was present in 2 cases $(22.22 \%)$ no other complications were found among proximal tibia fracture patients who were operated with MIPO technique. So MIPO technique is superior to ORIF and should be preferred whenever possible.

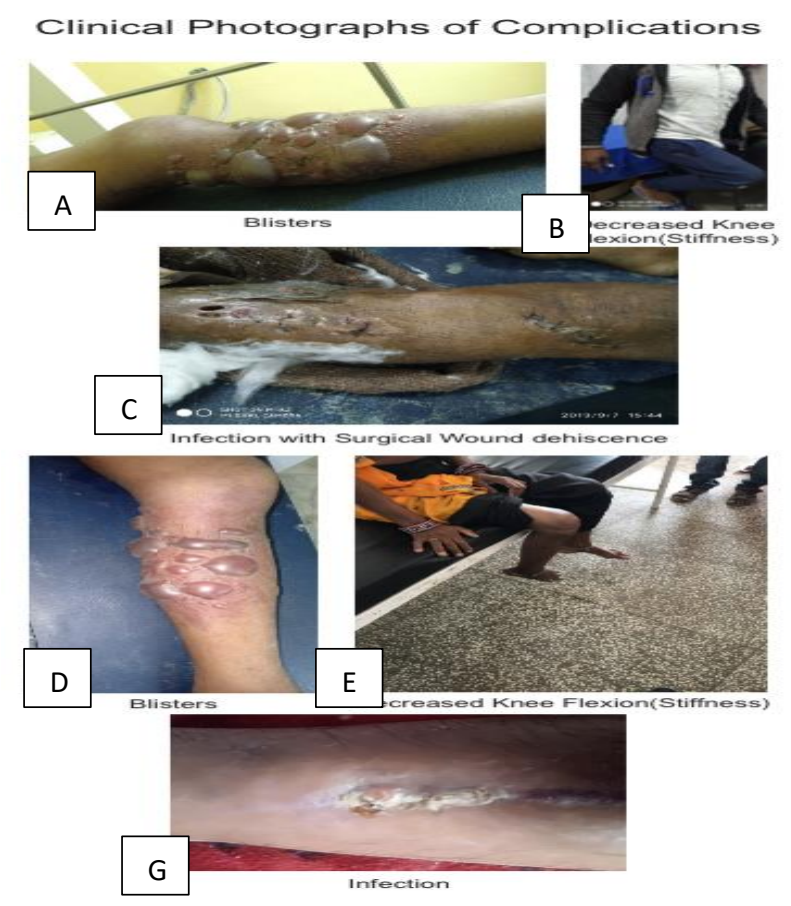

Figure 2: Clinical complications.

\section{DISCUSSION}

The distal femur and proximal tibia fractures (fracture around knee joint) result from high energy trauma. These fractures usually have intraarticular extension and are associated with metaphyseal comminution. When there is associated coronal plane extension and extensive comminution of these fractures generally preclude the use of traditional implant like fixed angle device, retrograde nail. The use of single lateral plate results in either nonunion or varus collapse in both distal femur and proximal tibia fractures. ${ }^{6,7}$

The introduction of locking compression plate (LCP/LISS) has provided the means to increase the rigidity of fixation of fractures around the knee joint in the presence of osteoporosis and severe juxta articular comminution. ${ }^{8}$ The LISS/LCP also allows minimally invasive insertion and preservation of vascularity to the fractured bone. Early clinical results following use of the LISS/LCP in the distal part of the femur have been promising as have been the early results of the use of LCP implants for other fractures. ${ }^{9-11}$

Out of 44 patients of distal femur fracture group 10 $(22.72 \%)$ had infection where as in proximal tibia fracture group $4(15.38 \%)$ out of 26 patients (all were operated by ORIF technique) had infection.

13 patients $(29.5 \%)$ of distal femur fracture group and 8 patients $(30.07 \%)$ of proximal tibia group (6 patients operated by ORIF, 2 patients operated by MIPO technique) had pain.

Varus deformity was found in 3 patients $(6.66 \%)$ of distal femur fracture patients. Whereas Valgus deformity was found in 4 patients $(15.38 \%)$ of proximal tibia fracture patients out of these 3 were operated by ORIF and 1 by MIPO.

Muscle wasting was found in 20 patients (40.44\%) of distal femur fracture patients. Limb shortening was found in 7 patients $(15.90 \%)$ of distal femur fracture. Limp was present in 17 patients $(38.60 \%)$ of distal femur fracture and 4 patients $(15 \%)$ of proximal tibia fracture out of these 4 were operated by ORIF and 1 by MIPO.

Delayed union was found in 2 patients $(4.54 \%)$ of distal femur fracture patients. Non-union with plate breakage and Non-union with plate loosening each were found in one patient $(2.25 \%)$. Extension lapse was found in 4 patients $(9.09 \%)$ of distal femur fracture and 1 patient $(5.88 \%)$ of proximal tibia fracture.

Out of all the patients operated with MIPO technique for proximal tibia fracture there was only 1 patient $(11.11 \%)$ in which valgus deformity was present, 1 patient $(11.11 \%)$ had limping and pain was present in 2 cases $(22.22 \%)$ no other complications were found among proximal tibia fracture patients who were operated with MIPO technique. So MIPO technique is superior to ORIF and should be preferred whenever possible.

\section{Limitations}

Limitations of the study were-The time duration was limited and the sample size was less.

\section{CONCLUSION}

We concluded that MIPO technique is superior to ORIF and should be preferred whenever fracture personality allows. Locking plates provide very good stability and fixation strength.

Complications are more common in distal femur fracture as compared to proximal tibia fractures. Infection is the most common complications of these fractures. 
Funding: No funding sources

Conflict of interest: None declared

Ethical approval: The study was approved by the institutional ethics committee

\section{REFERENCES}

1. Egol KA. Biomechanics of locked plates and screws. Orthop Trauma. 2004;18;8.

2. Perren SM. Point contact fixator: part 1. scientific background, design and application. Injury. 1995;22(1):1-10.

3. Perren SM. Physical and biological aspect of fracture healing with special reference to internal fixation. Clin orthop. 1979;138:175-96.

4. Cordy HRJ, Perren SM. In vivo measurement of bending stiffness in fracture healing. Biomed Eng Online. 2003;2:8.

5. Perren SM. Evolution of internal fixation of long bone fractures. The scientific basis of biological internal fixation: choosing a new balance between stability and biology JBJS Br. 2002;84:1093-110.

6. Jazrawi LM, Kummer FJ, Simon JA, Bai B, Hunt SA, Egol KA, Koval KJ. New technique for treatment of unstable distal femur fractures by locked double plating: case report and biomechanical evaluation. J Trauma. 2000;48:87-92.

7. Sanders R, Swiontkowski M, Rosen H, Helfet D. Double-plating of comminuted, unstable fractures of the distal part of the femur. J Bone Joint Surg Am. 1991;73:341-6.

8. Kregor PJ, Stannard JA, Zlowodzki M, Cole PA. Treatment of distal femur fractures using the less invasive stabilization system: surgical experience and early clinical results in 103 fractures. J Orthop Trauma. 2004;18:509-20.

9. Krettek C, Tscherne H. Transarticular joint reconstruction and Indirect Plate Osteosynthesis for complex distal supracondylar femoral fractures. Injury. 1997;28:31-41.

10. Rockwood CA, Green DP, Bucholz RW, eds. Fractures in adults, $4^{\text {th }}$ ed. Philadelphia: LippincottRaven. 1996.

11. Drake R, Vogl AW, Mitchell A. Henry Gray's Anatomy Anatomy for Students. Churchill Livingstone. 2009;513-7.

Cite this article as: Kumar S, Khichar $\mathrm{H}$. Assessment of complications in treating the fracture around knee joint by using locking compression plate. Int J Res Orthop 2021;7:386-90. 